\title{
URBAN WOOD/COAL CO-FIRING IN THE BELLEFIELD BOILERPLANT
}

\section{QUARTERLY TECHNICAL PROGRESS REPORT}

\author{
AUGUST 15 - NOVEMBER 15, 2000
}

James T. Cobb, Jr.

Gene E. Geiger

William W. Elder III

March 7, 2001

Award No. DE-FG26-00NT40808

By: Department of Chemical and Petroleum Engineering University of Pittsburgh

1249 Benedum Hall

Pittsburgh, PA 15261

For: U. S. Department of Energy

National Energy Technology Laboratory

Pittsburgh, Pennsylvania 
Morgantown, West Virginia 
This report was prepared as an account of work sponsored by an agency of the United States Government. Neither the United States Government nor any agency thereof, nor any of their employees, makes any warranty, express or implied, or assumes any legal liability or responsibility for the accuracy, completeness, or usefulness of any information, apparatus, product, or process disclosed, or represents that its use would not infringe privately owned rights. Reference herein to any specific commercial product, process, or service by trade name, trademark, manufacturer, or otherwise does not necessarily constitute or imply its endorsement, recommendation, or favoring by the United States Government or any agency thereof. The views and opinions of authors expressed herein do not necessarily state or reflect those of the United States Government or any agency thereof. 


\begin{abstract}
During the second quarter, important preparatory work was continued so that the experimental activities can begin toward the end of the third quarter or early in the fourth quarter. The Environmental Questionnaire was submitted to the U.S.DOE National Energy Technology Laboratory (NETL), after thorough review by the Bellefield Boiler Plant (BBP). Letters were submitted to the Allegheny County Health Department (ACHD) and the Pennsylvania Department of Environmental Protection (PADEP) to seek R\&D variances for permits at the BBP, the J. A. Rutter Company (JARC), and Emery Tree Service (ETS) for their portion of the project. Memoranda of understanding were executed by the University of Pittsburgh (University) with the BBP, JARC and ETS. Construction wood was collected from Thompson Properties. Discussions were held with the BBP and Energy Systems Associates (ESA), the BBP's engineering consultant. Presentations describing the University of Pittsburgh Wood/Coal Co-Firing Program were provided to the American Chemical Society (ACS), the Federal Energy Management Program (FEMP), the Upgraded Coal Interest Group (UCIG) of the Electric Power Research Institute (EPRI), the Engineering Center for Environment and Energy (ECEE) of the University of Pittsburgh, the Pittsburgh Coal Conference (PCC), the Pennsylvania Ethanol Workshop, BioEnergy 2000 and the Kick-Off Meeting of the Biomass Cofiring Opportunities Solicitation Projects.
\end{abstract}




\section{TABLE OF CONTENTS}

Abstract iii
Introduction 1
Executive Summary 2
Experimental 4
Results and Discussion 5

Environmental Issues 5

Wood Supply 5

Plant Operations 6

Reports and Presentations 8

Outside Contacts 9

Administrative Aspects 9

Plan for the Next Quarter $\quad 11$

Conclusions 12

References 13

List of Acronyms and Abbreviations 14 


\section{INTRODUCTION}

This second quarterly technical progress report describes work done during the second three-month period of the University of Pittsburgh's project on "Urban Wood/Coal Co-firing in the Bellefield Boilerplant."

This report describes the activities of the project team during the reporting period. The

principal work has focused upon environmental issues, wood supply, plant operations and reporting. 


\section{EXECUTIVE SUMMARY}

During the second quarter, work continued on environmental issues, wood supply, plant operations, and reporting. Several outside contacts were made.

\section{EXPERIMENTAL}

During the second quarter of the project, plans continued to be developed for experimental work at the Bellefield Boiler Plant (BBP), which is expected to begin toward the end of the third quarter or early in the fourth quarter.

\section{RESULTS AND DISCUSSION}

$\underline{\text { Environmental Issues }}$

The Environmental Questionnaire was submitted to the National Energy Technology Laboratory (NETL).

A letter was drafted for submission to the Allegheny County Health Department (ACHD), requesting an $R \& D$ variance to the boilerplant's operating permit for the project.

Wood Supply

A memoranda of understanding (MOU) were executed with J. A. Rutter Company (JARC) and Emery Tree Service (ETS).

Mr. Elder, the Research Associate for the project, viewed a demonstration of Universal Refiner's Contender Model.

Construction wood was collected from Thompson Properties. 
$\underline{\text { Plant Operations }}$

A MOU was executed with BBP. A project review meeting was held with BBP, at which the draft test plan was reviewed.

Regular group meetings of the project team began.

\section{Reporting}

Presentations were given to the American Chemical Society (ACS), the Federal Energy Management Program (FEMP), the Upgraded Coal Interest Group (UCIG) of the Electric Power Research Institute (EPRI), the Pittsburgh Coal Conference (PCC) and BioEnergy 2000.

\section{$\underline{\text { Outside Contacts }}$}

The project team participated in meetings of the EPRI Biomass Interest Group (BIG) and the Pennsylvania Ethanol Workshop. It arranged for a visit to the BBP by staff of the National Energy Technology Laboratory (NETL) and Parsons.

$\underline{\text { Plan for the Next Quarter }}$

During the third quarter from November 15, 2000 through February 15, 2001, work will continue toward obtaining permit variances from the ACHD and the PADEP. Work will also continue on acquiring additional construction wood, grinding it and blending it with coal in preparation for tests at BBP.

Planning will continue for the tests at the BBP. It is hoped that the first test burn can be completed by the end of the third quarter, but the principal portion of the test program is not expected before the fourth quarter. 


\section{EXPERIMENTAL}

Wood/coal cofiring in this project will be conducted at the Bellefield Boiler Plant (BBP) in the Oakland District of Pittsburgh. Two sources of construction wood will be identified. Wood from one source will be tub-ground by J. A. Rutter Company (JARC) of Monroeville, PA. Wood from the second source will be milled by Emery Tree Service (ETS) at Indianola, PA. The wood will be blended with coal at the Mon Valley Transportation Company (MVTC) in Glassport, PA by personnel from JARC and MVTC.

During the second quarter of the project, plans continued to be developed for experimental work, which is expected to begin late in the third quarter or early in the fourth quarter. 


\title{
RESULTS AND DISCUSSION
}

\section{ENVIRONMENTAL ISSUES}

\author{
Environmental Questionnaire
}

The Environmental Questionnaire was approved early in the second quarter by the Bellefield Boiler Plant (BBP) and the Environmental Health and Safety Department of the University of Pittsburgh (University). It was submitted on August 21 to Lloyd Lorenzi, Environmental Officer, U.S.DOE National Energy Technology Laboratory (NETL).

$\underline{\text { Variances to Permits }}$

In early November the project team drafted a letter for submission by the University, on behalf of the BBP, to the Allegheny County Health Department (ACHD), requesting an R\&D variance to the boilerplant's operating permit for the project. It was given to the BBP for its approval. After BBP approval, it is expected to be submitted to ACHD early in the third quarter.

The Pennsylvania Department of Environmental Protection (PADEP) regulates the operations of J. A. Rutter Company (JARC) and Emery Tree Service (ETS) through a procedure known as "permit by rule." Early in the third quarter the project team will provide a letter to PADEP describing the provenance of the construction wood to be processed at JARC and ETS and seeking an extension of the "permit by rule" at both companies for this project.

\section{WOOD SUPPLY}

\section{Memoranda of Understanding (MOU)}

On September 22 a signed memorandum of understanding (MOU) was received from JARC. On September 25 a signed MOU was received from ETS.

JARC began receiving construction wood waste from Thompson Properties in midOctober. The wood was collected in roll-off containers at a condominium construction site 
being developed by Thompson Properties. The wood consisted of trim-ends of framing lumber, mixed with a small amount of particleboard.

Discussion with Parties

On September 6 Mr. Elder, the Research Associate for the project, visited Advanced Enterprises Recycling, Inc., in Newark, NJ to view a demonstration of Universal Refiner's Contender Model as it ground whole logs. This is an "anti-tub grinder." It utilizes the "panand-disk method." Therefore it has more knife-like edges and produces a more chip-like material with fewer fines than a tub grinder. Advanced Enterprises operates an urban wood recycling center where it produces a variety of mulches. Universal Refiner had been expecting to grind pallet and similar type woods to a chuck-like mulch as a demonstration that day for Advanced Enterprises' executives. Unfortunately the executives were unexpectedly unavailable, and the demonstration was moved to Nature's Choice Corporation's composting facility in Lyndhurst, NJ. There the urban tree residues were ground to a stringy mulch for composting. Universal Refiner had hoped to demonstrate their machine to JARC on their way from New Jersey to the Mid-West to deliver it to a customer. However, they were unable to obtain a change in their highway permits for an oversized load in time for a trip to JARC.

Mr. Elder met with JARC November 6 to examine the construction wood that was tubground by a modified method for the project. On November 10 JARC was authorized to grind 30-tons of construction wood waste for the project. The wood was primarily the material JARC had collected from Thompson Properties with some pallet wood added to get to the required amount of material.

\section{PLANT OPERATIONS}

\section{$\underline{\text { Memorandum of Understanding (MOU) }}$}

A second draft of the MOU with BBP was received from BBP on September 7. The second draft of the MOU was approved by the University on October 27. It was signed by BBP on November 1 and by the University on November 3.

\section{Discussions with BBP and ESA}

On September 21 the project team met with key personnel of the BBP. In the meeting the following topics were discussed: 
- $\quad$ decision-making concerning boiler operating parameters during the test periods by personnel of Energy Systems Associates (ESA), the engineering contractor for BBP;

- $\quad$ schedule for loading wood/coal blends on railcars and transferring each blend from its railcar to the bunker of Boiler \#1 and then on to Boiler\#1 for each test;

- $\quad$ stack testing by equipment from only the U.S.DOE/NETL during Phase I;

- $\quad$ presence of antifreeze on coal piles, starting sometime in November;

- data collection by project team members from the University;

- $\quad$ calculation of weight of wood/coal blend fed, using the volume of the dump bucket at the front of the grate, its frequency of filling, and the density of the blend;

- $\quad$ need for the University to inform the neighborhood about the wood/coal cofiring test program.

A draft test plan was delivered to the BBP and ESA on September 22. A meeting was held on November 8 with personnel from ESA to discuss the test plan and the role of ESA in the conduct of the test program and the analysis of its results (including modeling).

\section{Planning and Activities of the Project Team}

Regular group meetings of the University project team began on November 6 . At the first meeting, the following topics were discussed:

- $\quad$ responsibility assigned to Mr. Elder to focus on wood acquisition, fuel blending and delivery and general operation of the test program;

- $\quad$ responsibility assigned to $\mathrm{Mr}$. $\mathrm{Li}$ to assure data collection during each test and to perform calculations of energy and material balances for each one;

- $\quad$ responsibility assigned to Mr. Wang to focus on (1) trace contaminants from wood/coal cofiring and (2) system modeling;

- collection of samples of coal and wood for testing, and the importance of moisture of the wood and coal;

- $\quad$ instrumentation from U.S.DOE/NETL; 
- $\quad$ letter to PADEP (solid waste regulators);

- $\quad$ visit to BBP to discuss data collection;

- $\quad$ agenda for the meeting with ESA on November 8;

- $\quad$ review of stoker boiler cofiring modeling, particularly (1) the program of McDermott Technologies Inc., as described on their homepage and (2) the use of Computational Fluid Dynamics as a modeling tool.

\section{REPORTS AND PRESENTATIONS}

Prof. Cobb, the project's Principal Investigator, gave a presentation on the University's Wood/Coal Cofiring Program at the American Chemical Society's (ACS's) national meeting in Washington, DC on August 21.

Mr. Elder, the project's Research Associate, gave a presentation on the University's Wood/Coal Cofiring Program at Energy 2000, the meeting to be held in Pittsburgh on August 22 by the Federal Energy Management Program (FEMP). The slides for his presentation can be seen on the Energy 2000 website,

\section{www.energy2000.ee.doe.gov.}

They describe the previous wood/coal cofiring demonstrations at the Pittsburgh Brewing Company and the Pittsburgh Research Center of the National Institute of Occupational Safety and Health (NIOSH), and the properties and availability of urban waste wood.

Mr. Elder also gave a presentation on the University's Wood/Coal Cofiring Program at the meeting on September 7 of he Upgraded Coal Interest Group (UCIG) of the Electric Power Research Institute (EPRI) at the Pittsburgh site of NETL.

At the 17th Annual International Pittsburgh Coal Conference (PCC) held in Pittsburgh, PA, on the morning of September 14 Prof. Cobb gave a presentation on the University's Wood/Coal Cofiring Program at the special symposium sponsored by the Engineering Center for Environment and Energy (ECEE) of the School of Engineering, University of Pittsburgh. That afternoon, Mr. Elder gave a similar presentation at the regular session on Biomass Cofiring at the conference. 
On September 19 Mr. Elder participated in the Pennsylvania Ethanol Workshop in Harrisburg, PA. He presented statistics that the project team has gathered on the availability of various cellulosic feedstocks, including corn stover and urban waste wood.

Prof. Cobb and Mr. Elder attended the meeting of the EPRI Biomass Interest Group (BIG), held on October 12 and 13 at the World Bank in Washington, DC. They offered a capsule report on the University's Wood/Coal Cofiring Program during the roundtable at the start of the meeting.

At BioEnergy 2000 in Buffalo, NY on October 17, Prof. Cobb gave a presentation on the University's Wood/Coal Cofiring Program.

On October 24 Prof. Cobb and Mr. Elder presented an overview of the project at the Kick-Off Meeting of the Biomass Cofiring Opportunities Solicitation Projects, held at the Pittsburgh site of NETL.

\section{OUTSIDE CONTACTS}

On October 20 the Farm Service Agency (FSA) of the U.S. Department of Agriculture (USDA) issued Notice CRP-378, "Reviewing and Recommending Applications for Biomass Pilot Projects." The project team expects to prepare an application for a pilot project in Pennsylvania for submission to the Pennsylvania State FSA Office in Harrisburg, PA by December 19, 2000.

On October 30 the project team made arrangements for staff members of NETL and Parsons to visit the BBP with the project team. NETL was preparing to visit the stoker boilerplant serving the U.S. Capitol and to offer advice to the staff of that boilerplant on its operation and upgrading. The visit to the BBP provided benchmarking and finding of fact in preparation for the visit to the boilerplant in Washington, DC.

\section{ADMINISTRATIVE ASPECTS}

This section provides a note of special actions, the monthly highlights, and a comparison of progress with the milestone chart.

$\underline{\text { Special Actions }}$ 
Jun Wang, a PhD candidate in the Department of Chemical \& Petroleum Engineering at the University of Pittsburgh, was appointed as the Graduate Student Researcher for this project.

\section{Monthly Highlights}

Here are the highlights of the second three-month period of the project.

\section{August 15 - September 15, 2000}

- The Environmental Questionnaire was submitted to NETL

- A presentation on the University's Wood/Coal Cofiring Program was provided in Washington, DC at the national ACS meeting.

- $\quad$ Presentations on the University's Wood/Coal Cofiring Program were provided in Pittsburgh, PA at the annual FEMP meeting, the fall meeting of the EPRI UCIG, the fall symposium of the University's ECEE, and the $17^{\text {th }}$ Annual International PCC.

- $\quad$ Mr. Elder visited Nature's Choice Corporation to observe the operation of Universal Refiner's Contender Model.

September 15 - October 15,2000

- $\quad$ Mr. Elder attended and spoke at the Pennsylvania Ethanol Workshop in Harrisburg, PA.

- $\quad$ A detailed planning meeting was held with the BBP, at which the draft test plan was reviewed.

- Jun Wang was appointed as the Graduate Student Researcher on the project.

- $\quad$ Prof. Cobb and Mr. Elder attended and participated in the fall EPRI BIG meeting at the World Bank in Washington, DC.

- $\quad$ MOUs were executed with JARC and ETS.

October 15 - November 15,2000 
- $\quad$ Presentations on the University's Wood/Coal Cofiring Program were provided at BioEnergy 2000 in Buffalo, NY and at the Kick-Off Meeting of the Biomass Cofiring Opportunities Solicitation Projects at NETL.

- $\quad$ Staff of NETL and Parsons visited the BBP.

- $\quad$ A MOU was executed with the BBP.

- $\quad$ A detailed planning meeting was held with ESA.

- $\quad$ Construction wood was collected from Thompson Properties.

\section{Comparison of Progress with Milestone Chart}

Task 1: The air quality permit $R \& D$ variance has been requested from the ACHD.

Task 2: JARC has tested a modification to its grinder. The resulting product appeared much chunkier than previous materials. ETS will modify its grinder and process construction wood as a further test.

Tasks 3 and 4: JARC has completed its portion of these two tasks. Another load of construction wood will be delivered to ETS for grinding.

Plans have been made for Tasks 5 through 7, but no substantive work has been done on them.

\section{PLAN FOR THE NEXT QUARTER}

During the third quarter from November 15, 2000 through February 15, 2001, work will continue toward obtaining permit variances from the ACHD and the PADEP. Work will also continue on acquiring additional construction wood, grinding it and blending it with coal in preparation for tests at BBP.

Planning will continue for the tests at the BBP. It is hoped that the first test burn can be completed by the end of the third quarter, but the principal portion of the test program is not expected before the fourth quarter. 


\section{CONCLUSIONS}

Project planning continues to be progressing well. The Environmental Questionnaire has been submitted, memoranda of understanding (MOU) have been executed with the Bellefield Boilerplant (BBP), J. A. Rutter Company (JARC) and Emery Tree Service (ETS). Construction wood has been collected from Thompson Properties. The test plan has been drafted and reviewed with BBP.

Numerous presentations and outside contacts have been made. Presentations have been given to the American Chemical Society (ACS), the Federal Energy Management Program (FEMP), the Upgraded Coal Interest Group (UCIG) of the Electric Power Research Institute (EPRI), the Pittsburgh Coal Conference (PCC) and BioEnergy 2000. The project team has participated in meetings of the EPRI Biomass Interest Group (BIG) and the Pennsylvania Ethanol Workshop. It has arranged for a visit to the BBP by staff of the National Energy Technology Laboratory (NETL) and Parsons. 


\section{REFERENCES}

None. 


\section{LIST OF ACRONYMS AND ABBREVIATIONS}

ACHD Allegheny County Health Department

ACS American Chemical Society

BBP Bellefield Boiler Plant

BIG Biomass Interest Group

ECEE Engineering Center for Environment and Energy

EPRI Electric Power Research Institute

ESA Energy Systems Associates

FEMP Federal Energy Management Program

FSA Farm Service Agency

JARC J. A. Rutter Company

MOU Memorandum of Understanding

NETL National Energy Technology Laboratory

NIOSH National Institute of Occupational Safety and Health

PADEP Pennsylvania Department of Environmental Protection

PCC Pittsburgh Coal Conference

UCIG Upgraded Coal Interest Group

USDA U.S. Department of Agriculture 